\title{
Self-interest and Altruism: Pluralism as a Basis for Leadership in Business
}

\author{
Jay Joseph \\ Correspondence: Jay Joseph, University of South Australia, Australia
}

\author{
Received: April 29, 2015 Accepted: May 11, 2015 Online Published: June 30, 2015 \\ doi:10.11114/bms.v1i2.921 \\ URL: http://dx.doi.org/10.11114/bms.v1i2.921
}

\begin{abstract}
The paper outlines the case for pluralism between self-interest (egoism) and altruism in business leadership. Scientific progression demonstrating pluralism is discussed, providing a multidisciplinary view of pluralism from evolutionary biology, psychology, moral philosophy, economic theory and organisational behavior. Findings show that myopic views of self-interest and altruism were once dominant in a number of fields however shifts in contemporary theory have provided a basis for pluralism in business leadership. Pluralism is yet to find grounding in leadership ethics, which still widely views "good leadership" through the lens of altruistic orientations. For leaders in business, the relevance of both self-interest and altruistic orientations are described. The paper seeks to address the divide between self-interest and altruism for business leaders, advocating for a realistic and pragmatic pluralistic approach to guide future research.
\end{abstract}

Keywords: self-interest, egoism, altruism, leadership, ethics

\section{Introduction}

The ethics of leadership have come under scrutiny in recent times, with the dilemma of self-interest (also referred to as egoism) and altruism at the center of the debate. Self-interest has played a prominent role in business, with a long history of normative and empirical work supporting the motivational and distributive advantages of self-interest (Rocha \& Ghoshal, 2006; Stead \& Stead, 1994). In contrast; leadership theories in business have elevated the role of altruistic orientations (Ciulla, 2013) which directly contrast the self-interest norm in the field. Many leadership theories now include altruism as a prominent factor (Fry \& Slocum, 2008; Sosik, Jung, \& Dinger, 2009), placing self-interest and altruism at odds within the capitalist model.

The following paper analyses the role that each factor plays, and seeks to provide a conceptual frame in which both opposing orientations are relevant in business. Historical work describes the essentiality of self-interest to business; however leadership theory distances itself from self-interest orientations with the field widely promoting altruism. The paper describes how both factors in isolation are unrealistic; drawing on contemporary research in multiple fields to demonstrate how pluralism is more representative of the human character.

The following piece contributes to the on-going demand for ethical approaches to leadership (Barbuto \& Wheeler, 2006; Dierendonck, 2011; Gardner, Cogliser, Davis, \& Dickens, 2011). Moral standing is considered the most important characteristic of leaders (Bennis, 2009), the nature of which will ultimately shape the organisational environment which the leader will influence (Goffee \& Jones, 2006; Kotter, 2007). Validating pluralist orientations restores a realistic view of leader values, which has subsequent implications for how we view leaders in business.

\section{Defining Self-interest and Altruism}

Self-interest and altruism are at the center of a variety of philosophical and societal discussions (Fehr \& Fischbacher, 2003). Origins of these discussions date back to the Sophists and ancient Greek philosophers who considered "self" as the center of ethical issues (Lefkowitz, 2003). Altruism emerged through the Axial Age (900-200 BCE) where many world religions adopted it as a core doctrinal value (Birnik \& Billsberry, 2008).

Self-interest (or egoism) commonly refers to concern with one's own interest or advantage (Feleke \& De Tavernier, 2011). The concept refers to an exclusive motivational position which serves the interest of one's self (Miller, 1999). Altruism on the other hand was first coined by Philosopher Auguste Comte (1798-1857), who used it to describe care for others. Altruism depicts a motivation and behavior that prioritizes the long-term welfare of another; independent of one's own interests (Jencks, 1990). Altruism is commonly associated with emotions such as compassion, sympathy and concern (Blum, 2009).

Dating back to the time of the Sophists, self-interest was viewed as the center for moral decisions (Lefkowitz, 2003). 
The Wealth of Nations gave this belief relevance in business, promoting the normative argument for self-interest (Rocha \& Ghoshal, 2006) with subsequent economic theory supporting the instrumental role it plays in an effective economy (Stead \& Stead, 1994). Self-interest became seen as the dominant motive in profit generating activities (Fry \& Slocum, 2008), with many economists viewing considerations outside of self-interest peripheral to business (Frank, Gilovich, \& Regan, 1993).

Whereas self-interest was frequently adopted across scholarly fields; the altruism concept underwent several fundamental iterations. 'Behavioral altruism' for instance, refers to an altruistic act that comes at a cost to the individual (Fehr \& Fischbacher, 2003). However, with behavioral altruism, the motivation for such action is unknown, and is historically considered to be self-interested in fields such as psychology and evolutionary biology. 'Psychological altruism' on the other hand is a motivational and behavioral state, where the motivation is considered to be a genuine interest in another's welfare (Post, 2002). For the purposes of discussion, a psychological definition of altruism is used.

Comte described egoism and altruism as together forming the human moral structure; a concept which has subsequently become central across several fields. The totality of self-interest and altruism to ethics is described by Jencks, who states that all actions and motives fall on a continuum between self-interest and altruism (Jencks, 1990). Despite differing perspectives on the relationship between these factors, the general view across disciplines is that self-interest and altruism provide a dual-framing for human ethics (Batson, 1996; Cahuc \& Kempf, 2000; Gates \& Steane, 2010; Singer \& van der Walt, 1987). Unique to this relationship is that both factors are diametrically opposed by definition (Kaplan, 2000); however, both are essential parts of the human moral structure.

\section{Myopic Viewpoints of Self-interest and Altruism}

The oppositional nature of self-interest and altruism often resulted in myopic viewpoints; favoring one factor while dismissing the other (Bloomfield, 2008). In most cases, self-interest as either a philosophical, normative or motivational orientation would hold stronger president. In moral philosophy, there is a strong case for 'ethical egoism' or more commonly 'enlightened self-interest', where pluralism between factors are acknowledged, yet self-interest is considered the basis of moral decisions (Rachels \& Rachels, 1986). The well-known analogy for enlightened self-interest "doing well by doing good" (Tribe, 1991) describes achieving self-interest outcomes through the inclusion of altruistic behaviors. These views typically drew on fields such as early evolutionary biology and psychology, which argue for behavioral altruism over psychological altruism (Kaler, 2000). In ethical discussions, these positions distance themselves from 'unenlightened self-interest'; or selfishness, where the pursuit of self-interest damages third party actors. Such approaches include Milbrath's (1984) application to business, stating that human's innate self-interest should be modified by altruistic values, and Dawson (2004) who proposes that entrepreneurial self-interest be tempered by morals. Despite the apparent plural application of self-interest and altruism in such theories, self-interest is posited as the beginning point for human motivation.

Alternatively, oppositional positions view altruistic orientations as the basis for moral decisions. Many of these views take strong positions against self-interest by defining moral standing based on selfless characteristics (Wyschogrod, 2002). Such arguments link the self-interest motive to corporate market failure (Carson, 2003), and state that Smith's original conceptualization of self-interest has been misunderstood as moral sentiments have been widely ignored (Stovall, Neill, \& Perkins, 2004). Altruistic positions are viewed as higher-level ethics, which transcend self-interest positions (Pavlovich \& Krahnke, 2012) and are historically linked to the social dimension of business including ethics in the medical profession (Swick, 1998) and corporate philanthropy (Shaw \& Post, 1993). These views negate the relevance of self-interest, which has been a theme viewed also in leadership theory.

\subsection{Leadership Theory}

Discussion in leadership theory has followed similar trends to that in other fields, with myopic views playing a dominant role in the debate. Leadership theorists favor one mode or the other, most vividly depicted in Avolio and Locke's debate on whether leaders should be selfish or altruistic (Avolio \& Locke, 2002; B. Avolio \& Locke, 2004). However, what is unique about leadership compared to other fields of study is the preference towards altruistic orientations rather than that of self-interest:

"Leadership is ethical when leaders are guided by altruism. The philosophical argument for altruism rests on the fact that a human being, by its very nature, does not begin and end in itself" (Mendonca, 2001, p. 268)

Several foundational leadership theories have bought altruistic characteristics to the fore including: servant leadership, self-sacrificial leadership, transformational leadership, charismatic leadership, spiritual leadership and authentic leadership (Fry \& Slocum, 2008; Sosik et al., 2009), all of which have included altruism in the morality of leadership to varying degrees. Transformational leadership is a typology where leaders facilitate vision and mission awareness, stimulating their followers in both fulfilling their own potential and achieving purposes beyond their own self-interest 
(Bass \& Avolio, 1994). The approach is often compared to transactional leadership; an oppositional typology where leaders are motivated by and concurrently motivate their followers by fulfilling personal interests and needs (Riggio \& Orr, 2004). Similarly, altruistic leadership describes helping behavior in leadership, and is associated with leadership that demonstrates sacrificial behavior, cooperation, charity, empowering others and service behavior (Sosik et al., 2009). Servant leadership describes a leadership style synonymous with behaviors of cooperation, collaboration, service, and transformation by going beyond one's own self-interest (Greenleaf, 2003). Servant leadership is defined by the desire of the leader to primarily serve (Greenleaf, 1970) and participate in the goals of others. Self-sacrificial leadership is defined as the abandonment of personal interests and privileges in the organisational setting (Choi \& Mai-Dalton, 1999); and finally, spiritual leadership is concerned with transcendence into a communal perspective (Fry, Hannah, Noel, \& Walumbwa, 2011).

Each typology has elevated altruism as a leadership characteristic, while subsequently dismissing the role of self-interest for business leaders. In an analysis of altruistic leadership; self-transcendent (altruistic) and self-enhancement (self-interest) leader orientations were analyzed, with findings showing a positive correlation between collective orientations and altruistic acts, however, no examination of the outcomes of self-interest were discussed (Sosik et al., 2009). Similarly, the analysis of the servant leadership structure used 11 potential dimensions, resulting in 5 factors, none of which included self-interest as a relevant factor (Barbuto \& Wheeler, 2006). Research showed transactional leadership is based on a teleological worldview and ethical egoism, however the transformational typology is posited as a superior mode derived from altruistic orientations and lodged within deontology (Aronson, 2001; Kanungo, 2001).The common theme throughout these studies was a lack of focus on self-interest, and subsequent adoption of a myopic view of leadership ethics.

As a result, pluralism has failed to be acknowledged in core leadership typologies. Analysis of follower motivation often included plural dimensions (Dierendonck, 2011; Shamir, House, \& Arthur, 1993), however, such analysis was not applied to leaders. In transformational leadership, theorists openly state that leaders carry both transformational, and the self-interest based transactional leadership trait (Bass \& Steidlmeier, 1999). Furthermore, research into transactional leadership showed that although the transactional trait was initially associated with self-interest orientations, transactional leaders can have altruistic orientations, however, this is grounded in an alternative worldview to transformational leaders (Kanungo, 2001). Leadership free of self-interest may be an ideology of leadership theorists; however research across multiple fields suggests that pluralism is a more realistic view of leadership ethics in business.

\section{Interdisciplinary Movement to Pluralism}

Despite seemingly myopic views arising surrounding the relationship between self-interest and altruism, development across a number of fields has seen pluralism between factors more widely recognized. Research in evolutionary biology has increasingly supported this basis. Darwin's Theory of Evolution is a process based on natural selection which is inherently self-interested (Komter, 2010). Evolutionary biologists believed that self-interest was genetic, with key works such as The Selfish Gene (Dawkins, 1976) providing support for this claim. Describing motivation outside of self-interest challenged this assumption. Altruism was therefore rationalized through theories such as Kinship Altruism (Hamilton, 1964), Reciprocal Altruism (Trivers, 1971) and Strong Reciprocity (Fehr \& Fischbacher, 2003) which described altruistic behavior through survival based self-interest. However, recent studies found that cooperation and sharing were essential parts of evolution (Bowles, 2006). Altruistic characteristics were found to be common among animals and humans, and were necessary factors that progressed the evolutionary process (Sussman \& Cloninger, 2011). Altruism and cooperation were found to be driven by a mixture of kinship, reciprocal and group selection processes (Nowak, 2006), which would either offer direct benefits for the actor (mutually beneficial cooperation) or indirect benefits (altruistic cooperation) (West, Griffin, \& Gardner, 2007). Sober and Wilson (1998) conclude that evolutionary biology has moved from a field that provided support for biological self-interest, to one which now offers an even-playing field where both self-interest and altruism are valid biological factors.

Supporting evolutionary biology, research in psychology has also moved to support pluralism. Historically, altruistic behaviors were described as undergirded by self-interest (Holmes, Miller, \& Lerner, 2002) and mediated by factors such as emotional closeness (Korchmaros \& Kenny, 2001). Theories such as Competitive Altruism Hypothesis stated that altruistic behaviors are enacted for reputational purposes (Hardy \& Vugt, 2006). Both self-interest and altruistic motivates have been empirically supported; however, the theories that emerged denote that these motives are undergirded by self-interest. Despite this trend, a number of theorists including Hoffman (1979) and Batson and Shaw (1991) introduced pro-social motives to the already accepted egoistic factors. Hoffman introduced the idea of Empathetic Distress, whereby one responds to another's welfare with helping behaviors (Hoffman, 2001; Hoffman, 1979, 1981). Hoffman notes that empathetic distress often competes with egoistic factors. Batson's Empathy-Altruism hypothesis makes similar claims, stating that empathy provides motivation to act altruistically (Batson, 2014). Empathy was established as a psychological basis for altruistic motives (De Waal, 2008), contradicting self-interest explanations 
for altruism. Batson's work has added to growing evidence for pluralism between factors, establishing that actors can be motivated by either self-interest or altruism (Simpson \& Willer, 2008). This supports social psychology research in value theory which now recognizes the coexistence of both self-transcendent (altruistic) and self-enhancement (self-interest) values (Boyd, Schmidt, \& Schwartz, 2008; Cieciuch \& Schwartz, 2012; Schwartz, 1992).

Economic theory has also undergone a similar progression. Smith's original work linked self-interest to the effective organisation and distribution of economic resources (Stead \& Stead, 1994). This ethic was used as the basis for early game and social exchange theory (Van Lange, 2000), in addition to influencing national and state level economic policy around the world (Zutshi, Creed, \& Sohal, 2009). The result being that many economists believed that motives outside of self-interest were irrelevant to business (Frank et al., 1993). However, myopic interpretations of the Wealth of Nations have been revised, with authors highlighting that Smith intended for self-interest to be mitigated by a variety of concerns with justice described as the foremost component (James \& Rassekh, 2000). Arguments for multiple motivations in economics state that self-interest is combined with values in making economic decisions (Sen, 2005). In distribution decisions, reasoning such as justice ethics have been introduced as alternative motives to self-interest (Fong, 2001). A number of economic redefinitions have resulted from such discussions, including introducing moral dimensions to the rational self-interest model (Etzioni, 2010; Meadowcroft, 2007), altruistic economics (Upton, 2010) and moving concepts such as utility beyond monetary measures to include emotional wellness and other factors (Smith, Brown, \& Rigdon, 2012).

Finally, research in organisational behavior has also provided empirical support for pluralism in the workplace. Research has explored helping behaviors in business (Grant \& Patil, 2012), volunteering behavior in organisations (Grant, 2012), social entrepreneurship (Miller, Grimes, McMullen, \& Vogus, 2012), and workplace forgiveness (Fehr \& Gelfand, 2012) all of which examine mixed motive approaches. These studies found multiple motives in organisational decision making, noting that human orientations for such behavior can be both altruistic and self-interested.

\subsection{Conceptualizing Pluralism}

Conceptualizing pluralism for business leaders is problematic for a number of reasons. Several reflective questions arise; what degree of self-interest leads to corruption? What degree of altruism is ethical? Several underlying assumptions form such questions; such as self-interest leading to negative outcomes, and altruism correlating with positive leadership outcomes; all of which require rigorous analysis none of which currently exists.

Additionally, the fact that two diametrically opposed factors can together form a unified construct is also problematic. Often when these questions are posed theorists adopt 'either/or' positions (Avolio \& Locke, 2002), however, pluralism maintains that both factors are essential. Attempts have also been made to combine self-interest and altruism to collapse the dichotomy between factors (Rocha \& Ghoshal, 2006), however, pluralism again negates this possibility. To understand the concept of pluralism, a clarified definition is required.

Pluralism is the recognition that both self-interest and altruism are genuine psychological factors within human morality. Subsequently, the concept has implications for leadership ethics. Although this paper stops short of prescriptive discussion, at a minimum:

1) No leader is exclusively self-interested; or, exclusively altruistic;

2) Typologies which choose a self-interest or altruistic moral lens; although useful, are idealistic in nature and will not be able to wholly understand the antecedents of leadership behavior;

3) Leadership ethics in business involve varying degrees of both self-interest and altruism.

Within pluralism, there are three common views on the dynamics between self-interest and altruism. Without prescribing one such approach, the three common typologies are listed as:

Trade-off view: One view states that the relationship between self-interest and altruism is one that elicits a trade-off between factors. For example, an actor who is highly self-interested will demonstrate low altruistic orientations, and vice versa. Jencks describes this as a continuum between factors, and that movement towards one will entail a movement away from the other (Jencks, 1990). As previously discussed, theorists who adopt this view are typically concerned with normative discussions;

Relative autonomy: The second view states that self-interest and altruism may negatively influence one another; however, this relationship is not exclusive, with both factors maintaining a degree of autonomy. Research in social psychology provided empirical support for this view, citing that self-interest and altruistic factors can concurrently be high or low (Frimer, Walker, Dunlop, Lee, \& Riches, 2011);

Progressive altruism: Progressive altruism is commonly seen in ethical discussions, and has emerged as a trend in leadership. Theories such as Kohlberg's Stages of Moral Development and Maslow's Hierarchy of Needs widely 
consider self-interest as the base or starting point for morality. These theories state that as an actor matures in their moral development there is a progressive movement away from the base levels of motivation toward higher-level altruistic orientations. Depending on the theory this may elicit a form of trade-off, however, movement between phases of development is often not conclusive, meaning that base orientations are either built upon or fluctuate between higher order orientations. This trend is in all of the named leadership theories, where a leader transcends self-interest into altruistic positions, however is rarely discussed and conceptually undefined.

Each of the three typologies have relevance in varying contexts, however further research is required in the application to business leadership, and in particular the result on business outcomes. As an initial step however, the acknowledgement of pluralism has several implications for how leadership in business is viewed.

\section{Applying Pluralism to Leadership in Business}

The establishment of pluralism in leadership has two clear implications for leadership theory. The first is the dismissal of myopic leadership typologies; and secondly, pluralism has implications for how we explore business leadership in the future.

Pluralism embraces the multiple motivates in human character, which directly contrasts the myopic views currently seen in leadership theory. Theories underlined exclusively by either self-interest or altruism are unscientific, and go against empirical evidence across evolutionary biology, economic theory, organisational behavior, and value theory in social psychology. Leadership typologies that dismiss the relevance of self-interest and instead promote only altruistic orientations are idealistic, and although research has linked altruistic characteristics to leader outcomes, these findings fall short of painting a holistic picture of leadership ethics. In business, pluralism evokes discussion involving the self-interest of owners and shareholders to include broader interests as part of the business ethic (Zimmerli, Richter, \& Holzinger, 2007). Emerging theory in business ethics support a plural view of business (Benkler, 2011; "Conscious Capitalism Australia," 2014; Murtaza, 2011; Smith et al., 2012), however this requires application in business leadership theory.

Pluralism also has implications for the exploration of antecedents of leadership behavior, with a plural view opening the field to a complete exploration of the effects of self-interest and altruism in leaders. Altruistic leadership orientations often highlight the charismatic, empowerment, and communal capabilities of leadership; however, organisational leaders today require a broader set of skills which are often linked to 'management' typologies. These can include the self-regulation of emotions, intellectual competence through the self-regulation of thought processes and beliefs, and action orientated-competence through the self-regulation of actions (Mendonca, 2001, p. 270). These traits are defined as having equal importance with the named altruistic leadership characteristics (Kotter 2008), of which self-interest may play a defining role. A myopic altruistic view limits the capacity to explore the antecedents of such management capabilities, with pluralism opening new doors to examine whether self-interest may lead to the ongoing development of these traits.

\section{References}

Aronson, E. (2001). Integrating leadership styles and ethical perspectives. Canadian Journal of Administrative Sciences / Revue Canadienne Des Sciences de l'Administration, 18(4), 244-256. http://doi.org/10.1111/j.1936-4490.2001.tb00260.x

Avolio, B. J., \& Locke, E. E. (2002). Contrasting different philosophies of leader motivation: Altruism versus egoism. The Leadership Quarterly, 13(2), 169-191. http://doi.org/10.1016/S1048-9843(02)00094-2

Avolio, B., \& Locke, E. (2004). Should leaders be selfish or altruistic? Ethics, the Heart of Leadership. Greenwood Publishing Group.

Barbuto, J. E., \& Wheeler, D. W. (2006). Scale development and construct clarification of servant leadership. Group \& Organization Management, 31(3), 300-326. http://doi.org/10.1177/1059601106287091

Bass, B., \& Avolio, B. J. (1994). Improving organizational effectiveness through transformational leadership. Thousand Oaks, CA: Sage Publications.

Bass, B., \& Steidlmeier, P. (1999). Ethics, character, and authentic transformational leadership behavior. The Leadership Quarterly, 10(2), 181-217. http://doi.org/10.1016/S1048-9843(99)00016-8

Batson, D. (2014). The Altruism Question: Toward a Social-Psychological Answer. New York, NY: Psychology Press.

Batson, D. C. (1996). Do prosocial motives have any business in business? Social Justice Research, 9(1), 7-25. http://dx.doi.org/10.1007/BF02197654

Batson, D., \& Shaw, L. (1991). Evidence for altruism: Toward a pluralism of prosocial motives. Psychological Inquiry, 
2(2), 107. http://dx.doi.org/10.1207/s15327965pli0202_1

Benkler, Y. (2011). The unselfish gene. Harvard Business Review, 89(7 /8), 77 - 85.

Bennis, W. (2009). On Becoming a Leader. Basic Books.

Birnik, A., \& Billsberry, J. (2008). Reorienting the business school agenda: The case for relevance, rigor, and righteousness. Journal of Business Ethics, 82(4), 985-999. http://doi.org/10.1007/s10551-007-9607-x

Bloomfield, P. (2008). Morality and self-Interest. New York: Oxford University Press.

Blum, L. (2009). Friendship, altruism and morality. Taylor \& Francis. http://works.bepress.com/lawrence_blum/4

Bowles, S. (2006). Group competition, reproductive levelling, and the evolution of human altruism. Science, 314(5805), 1569-1572. http://dx.doi.org/10.1126/science.1134829

Boyd, E., Schmidt, P., \& Schwartz, S. (2008). Bringing values back in the adequacy of the European social survey to measure values in 20 countries. Public Opinion Quarterly, 72(3), 420-445. http://dx.doi.org/10.1093/poq/nfn035

Cahuc, P., \& Kempf, H. (2000). Is altruism socially efficacious? La Revue du MAUSS, (15), 223-246.

Carson, T. (2003). Self-interest and business ethics: Some lessons of the recent corporate scandals. Journal of Business Ethics, 43, 389-394. http://dx.doi.org/10.1023/A:1023013128621

Choi, Y., \& Mai-Dalton, R. R. (1999). The model of followers' responses to self-sacrificial leadership: An empirical test. The Leadership Quarterly, 10(3), 397-421. http://doi.org/10.1016/S1048-9843(99)00025-9

Cieciuch, J., \& Schwartz, S. (2012). The number of distinct basic values and their structure assessed by PVQ-40. Journal of Personality Assessment, 94(3), 321-328. http://doi.org/10.1080/00223891.2012.655817

Ciulla, J. B. (2013). Leadership ethics. In International Encyclopedia of Ethics. Blackwell Publishing Ltd. http://dx.doi.org/10.1002/9781444367072.wbiee370

Conscious Capitalism Australia. (2014). http://www.consciouscapitalism.org.au/

Dawkins, R. (1976). The Selfish Gene. New York: Oxford University Press.

Dawson, S. (2004). Balancing self-interest and altruism: Corporate governance alone is not enough. Corporate Governance: An International Review, 12(2), 130-133. http://doi.org/10.1111/j.1467-8683.2004.00351.x

De Waal, F. (2008). Putting the altruism back into altruism: The evolution of empathy. Annual Review of Psychology, 59, 279-300. http://dx.doi.org/10.1146/annurev.psych.59.103006.093625

Dierendonck, D. van. (2011). Servant leadership: A review and synthesis. Journal of Management, 37(4), 1228-1261. http://doi.org/10.1177/0149206310380462

Etzioni, A. (2010). Moral dimension: Toward a new economics. Simon and Schuster.

Fehr, E., \& Fischbacher, U. (2003). The nature of human altruism. Nature, 425, 785-791. http://dx.doi.org/10.1038/nature02043

Fehr, R., \& Gelfand, M. (2012). The forgiving organization: A multilevel model of forgiveness at work. Academy of Management Review, 37(4), 664-688. http://doi.org/10.5465/amr.2010.0497

Feleke, M. K., \& De Tavernier, J. (2011). Selfishness, self-interest, and self-love. Vidyajyoti Journal of Theological Reflection. https://lirias.kuleuven.be/handle/123456789/310626

Fong, C. (2001). Social preferences, self-interest, and the demand for redistribution. Journal of Public Economics, 82(2), 225-246. http://doi.org/10.1016/S0047-2727(00)00141-9

Frank, R. H., Gilovich, T., \& Regan, D. T. (1993). Does studying economics inhibit cooperation? The Journal of Economic Perspectives, 7(2), 159-171. http://dx.doi.org/10.1257/jep.7.2.159

Frimer, J. A., Walker, L. J., Dunlop, W. L., Lee, B. H., \& Riches, A. (2011). The integration of agency and communion in moral personality: Evidence of enlightened self-interest. Journal of Personality and Social Psychology, 101(1), 149-163. http://doi.org/10.1037/a0023780

Fry, L., \& Slocum, J. (2008). Maximising the triple bottom line through spiritual leadership. Organisational Dynamics, 37(1). http://dx.doi.org/10.1016/j.orgdyn.2007.11.004

Fry, L. W., Hannah, S. T., Noel, M., \& Walumbwa, F. O. (2011). Impact of spiritual leadership on unit performance. The Leadership Quarterly, 22(2), 259-270. http://doi.org/10.1016/j.leaqua.2011.02.002

Gardner, W. L., Cogliser, C. C., Davis, K. M., \& Dickens, M. P. (2011). Authentic leadership: A review of the literature 
and research agenda. The Leadership Quarterly, 22(6), 1120-1145. http://doi.org/10.1016/j.leaqua.2011.09.007

Gates, D. K., \& Steane, P. (2010). Values in economic decisions and policymaking. International Journal of Public Administration, 33(6), 289-301. http://doi.org/10.1080/01900690903455639

Goffee, R., \& Jones, G. (2006). Why Should Anyone be Led by You? What it Takes to be an Authentic Leader. Harvard Business Press. http://dx.doi.org/10.1108/hrmid.2006.04414gae.001

Grant, A. (2012). Giving time, time after time: Work design and sustained employee participation in corporate volunteering. Academy of Management Review, 37(4), 589-615. http://dx.doi.org/10.5465/amr.2010.0280

Grant, A., \& Patil, S. (2012). Challenging the norm of self-interest: Minority influence and transitions to helping norms in work units. Academy of Management Review, 37(4), 547-568. http://doi.org/10.5465/amr.2010.0437

Greenleaf, R. (2003). The Servant-Leader Within: A Transformative Path. Paulist Press.

Greenleaf, R. (1970). The Servant as Leader. Indianapolis, IN: Greenleaf Center.

Hamilton, W. D. (1964). The genetical evolution of social behaviour. II. Journal of Theoretical Biology, 7(1), 17-52. http://doi.org/10.1016/0022-5193(64)90039-6

Hardy, C., \& Vugt, M. (2006). Nice guys finish first: The competitive altruism hypothesis. Personality and Social Psychology Bulletin, 32(10), 1402-1413. http://doi.org/10.1177/0146167206291006

Hoffman, M. (2001). Empathy and Moral Development: Implications for Caring and Justice. Cambridge University Press.

Hoffman, M. L. (1979). Development of moral thought, feeling, and behavior. American Psychologist, 34(10), 958-966. http://doi.org/10.1037/0003-066X.34.10.958

Hoffman, M. L. (1981). Is altruism part of human nature? Journal of Personality and Social Psychology, 40(1), 121137. http://doi.org/10.1037/0022-3514.40.1.121

Holmes, J., Miller, D., \& Lerner, M. (2002). Committing altruism under the cloak of self-interest: The exchange fiction. Journal of Experimental Social Psychology, 38(2), 144-151. http://dx.doi.org/10.1006/jesp.2001.1494

Jencks, C. (1990). Varieties of altruism. In J. J. Mansbridge (Ed.), Beyond self-interest. University of Chicago Press.

Kaler, J. (2000). Reasons to be ethical: Self-interest and ethical business. Journal of Business Ethics, 27(1-2), 161-173. http://doi.org/10.1023/A:1006450018660

Kanungo, R. N. (2001). Ethical values of transactional and transformational leaders. Canadian Journal of Administrative Sciences / Revue Canadienne Des Sciences de l'Administration, 18(4), 257-265. http://doi.org/10.1111/j.1936-4490.2001.tb00261.x

Kaplan, S. (2000). New ways to promote proenvironmental behavior: Human nature and environmentally responsible behavior. Journal of Social Issues, 56(3), 491-508. http://doi.org/10.1111/0022-4537.00180

Komter, A. (2010). The evolutionary origins of human generosity. International Sociology, $25(3), 443-464$. http://doi.org/10.1177/0268580909360301

Korchmaros, J., \& Kenny, D. (2001). Emotional closeness as a mediator of the effect of genetic relatedness on altruism. Psychological Science, 12(3).

Kotter, J. (2007). Leading change: Why transformation efforts fail. http://hbr.org/2007/01/leading-change-why-transformation-efforts-fail/ar/1

Kotter, J. (2008). Force For Change: How Leadership Differs from Management. Simon and Schuster.

Lefkowitz, J. (2003). Ethics and values in industrial-organizational psychology. Routledge.

Meadowcroft, J. (2007). Altruism, self-interest, and the morality of the private sector: An Austrian approach. Journal of Markets \& Morality, 10(2). http://www.marketsandmorality.com/index.php/mandm/article/view/237

Mendonca, M. (2001). Preparing for ethical leadership in organizations. Canadian Journal of Administrative Sciences / Revue Canadienne Des Sciences de l'Administration, 18(4), 266-276. http://doi.org/10.1111/j.1936-4490.2001.tb00262.x

Milbrath, L. (1984). A proposed value structure for a sustainable society. The Environmentalist, 4(2), 113-124. http://dx.doi.org/10.1007/BF02337286

Miller, D. T. (1999). The norm of self-interest. American Psychologist, 54, $1053-1060$. http://doi.org/10.1037/0003-066X.54.12.1053 
Miller, T., Grimes, M., McMullen, J., \& Vogus, T. (2012). Venturing for others with heart and head: How compassion encourages social entrepreneurship. Academy of Management Review, 37(4), 616-640. http://doi.org/10.5465/amr.2010.0456

Murtaza, N. (2011). Pursuing self-interest or self-actualization? From capitalism to a steady-state, wisdom economy. Ecological Economics, 70(4), 577-584. http://doi.org/10.1016/j.ecolecon.2010.10.012

Nowak, M. A. (2006). Five rules for the evolution of cooperation. Science, 314(5805), 1560-1563. http://doi.org/10.1126/science.1133755

Pavlovich, K., \& Krahnke, K. (2012). Empathy, connectedness and organisation. Journal of Business Ethics, 105(1), 131-137. http://doi.org/10.1007/s10551-011-0961-3

Post, S. (2002). Altruism \& altruistic love: Science, philosophy, \& religion in dialogue. Oxford University Press.

Rachels, J., \& Rachels, S. (1986). Ethical egoism. In The elements of moral philosophy. McGraw Hill.

Riggio, R. E., \& Orr, S. S. (2004). Improving Leadership in Nonprofit Organizations. San Francisco, CA: Jossey-Bass.

Rocha, H. O., \& Ghoshal, S. (2006). Beyond self-interest revisited. Journal of Management Studies, 43(3), 585-619. http://doi.org/http://dx.doi.org/10.1111/j.1467-6486.2006.00603.x

Schwartz, S. (1992). Universals in the content and structure of Values: Theoretical Advances and Empirical Tests in 20 Countries. Advances in Experimental Social Psychology, 25, 1-62. http://dx.doi.org/10.1016/s0065-2601(08)60281-6

Sen, A. (2005). Why exactly is commitment important for rationality? Economics and Philosophy, 21(01), 5-14. http://doi.org/10.1017/S0266267104000355

Shamir, B., House, R., \& Arthur, M. (1993). The motivational effects of Charismatic Leadership: A self-concept based theory. Organization Science, 4(4), 577-594. http://doi.org/10.1287/orsc.4.4.577

Shaw, B., \& Post, F. (1993). A moral basis for corporate philanthropy. Journal of Business Ethics, 12(10), 745. http://dx.doi.org/10.1007/BF00881305

Simpson, B., \& Willer, R. (2008). Altruism and indirect reciprocity: The interaction of person and situation in prosocial behavior. Social Psychology Quarterly, 71(1), 37-52. http://doi.org/10.1177/019027250807100106

Singer, A. E., \& van der Walt, N. T. (1987). Corporate conscience and foreign divestment decisions. Journal of Business Ethics, 6(7), 543. http://dx.doi.org/10.1007/BF00383745

Smith, D., Brown, S., \& Rigdon, M. (2012). A new view of utility: Maximising "optimal investment." In Moving Beyond Self-Interest: Perspectives from evolutionary biology, neuroscience, and the social sciences.

Sober, E., \& Wilson, D. (1998). Unto Others: The evolution and psychology of unselfish behavior. Harvard University Press.

Sosik, J., Jung, D., \& Dinger, S. (2009). Values in authentic action examining the roots and rewards of altruistic leadership. Group \& Organization Management, 34(4), 395-431. http://doi.org/10.1177/1059601108329212

Stead, E., \& Stead, J. (1994). Can humankind change the economic myth? Paradigm shifts necessary for ecologically sustainable business. Journal of Organizational Change Management, 7(4), 15-31. http://doi.org/10.1108/09534819410061351

Stovall, S., Neill, J., \& Perkins, D. (2004). Corporate governance, internal decision making, and the invisible hand. Journal of Business Ethics, 51(2), 221-227. http://dx.doi.org/10.1023/B:BUSI.0000033615.22269.e3

Sussman, R. W., \& Cloninger, C. R. (2011). Origins of Altruism and Cooperation. Springer. http://dx.doi.org/10.1007/978-1-4419-9520-9

Swick, H. M. (1998). Academic medicine must deal with the clash of business and professional values. Journal of the Association of American Medical Colleges, http://dx.doi.org/10.1097/00001888-199807000-00010

Tribe, D. (1991). Doing well by doing good. Agricultural research: feeding and greening the world., 135pp.

Trivers, R. L. (1971). The evolution of reciprocal altruism. The Quarterly Review of Biology, 46(1), 35-57. http://dx.doi.org/10.1086/406755

Upton, R. (2010). Development of altruistic economics. www.altruists.org.

Van Lange, P. A. M. (2000). Beyond self-interest: A set of propositions relevant to interpersonal orientations. European 
Review of Social Psychology, 11(1). http://dx.doi.org/10.1080/14792772043000068

West, S., Griffin, A., \& Gardner, A. (2007). Social semantics: altruism, cooperation, mutualism, strong reciprocity and group selection. Journal of Evolutionary Biology, 20(2), 415-432. http://dx.doi.org/10.1111/j.1420-9101.2006.01258.x

Wyschogrod, E. (2002). Pythagorean bodies and the body of altruism. In Altruism and Altruistic Love. New York: Oxford University Press. http://dx.doi.org/10.1093/acprof:oso/9780195143584.003.0004

Zimmerli, W., Richter, R., \& Holzinger, M. (2007). Corporate ethics and corporate governance. Berlin: Springer. http://dx.doi.org/10.1007/978-3-540-70818-6

Zutshi, A., Creed, A., \& Sohal, A. (2009). Child labour and supply chain: Profitability or (mis)management. European Business Review, 21(1), 42 - 63. http://dx.doi.org/10.1108/09555340910925175

\section{(cc) EY}

This work is licensed under a Creative Commons Attribution 3.0 License. 